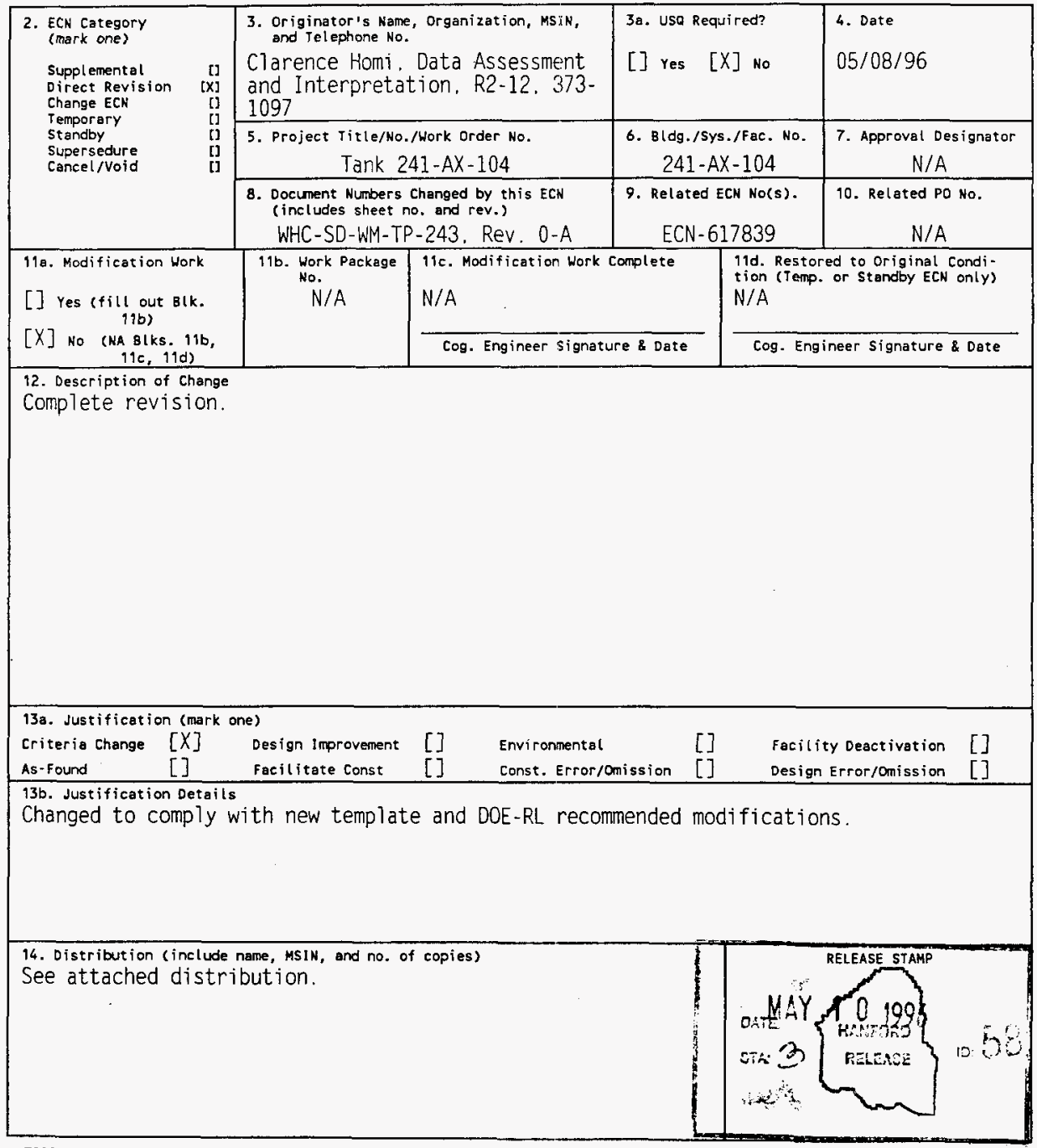




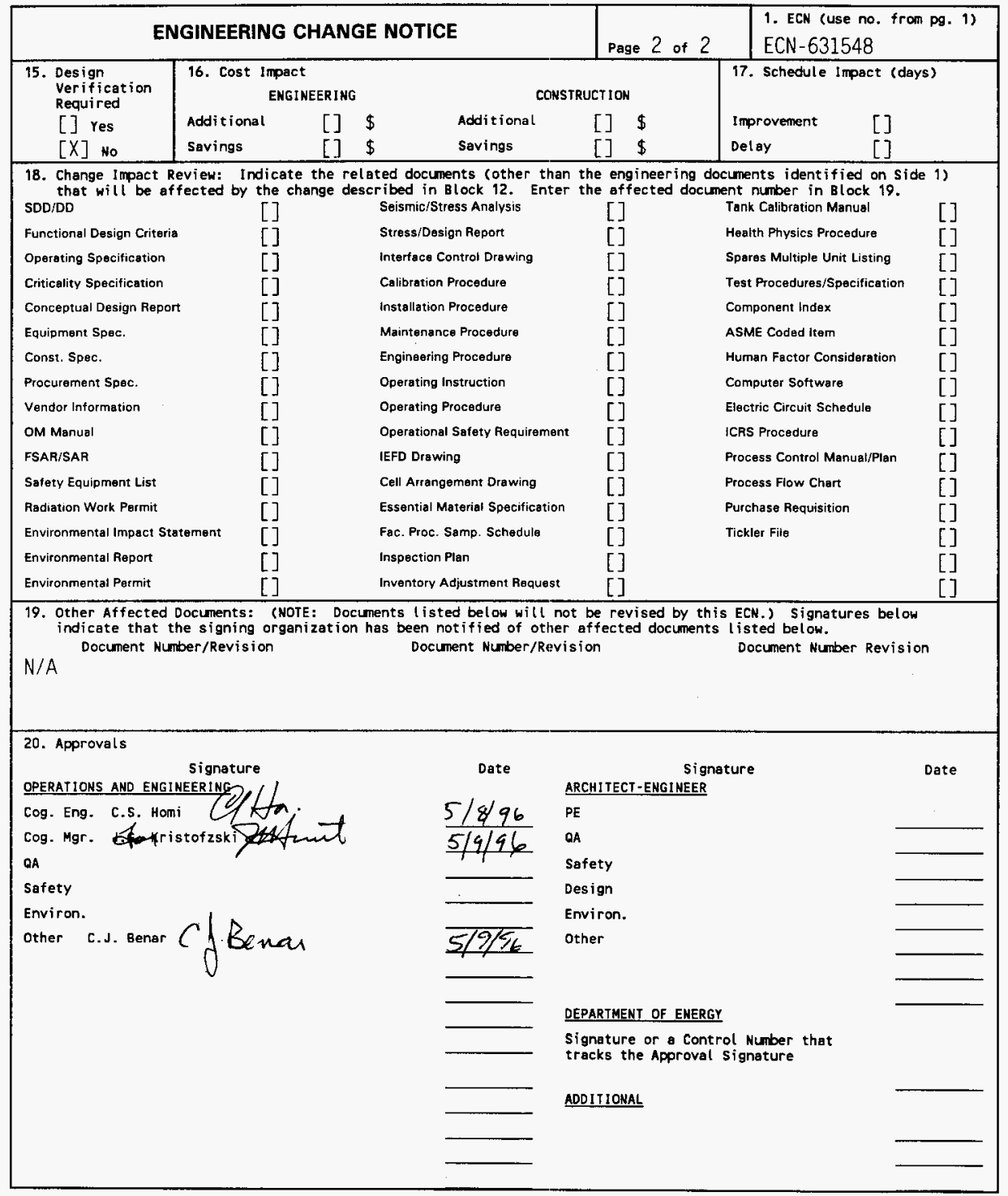




\section{Tank 241-AX-104 Tank Characterization Plan}

C. S. Homi

Westinghouse Hanford Company. Richland. WA 99352

U.S. Department of Energy Contract DE-AC06-87RL10930

$\begin{array}{lll}\text { EDT/ECN: } & \text { ECN-631548 } & \text { UC: } 2070 \\ \text { Org Code: } & 79200 & \text { Charge Code: } \\ \text { B\&R Code: } & \text { EW } 3120074 & \text { Total Pages: } 9\end{array}$

Key Words: Characterization, General Safety Issues, Specific Safety Issues. Information Requirements, Schedule

Abstract: This document is a plan that identifies the information needed to address relevant issues concerning short-term and long-term storage and Tong-term management of single-shell tank 241-AX-104.

TRADEMARK DISCLAIMER. Reference herein to any specific comercial product, process, or service by trade name, trademerk, manufacturer, or otherwise, does not necessarily constitute or inply its endorsenent, recomendation, or favoring by the United States Goverment or any agency thereof or its contractors or subcontractors.

Printed in the United States of America. To obtain copies of this document, contact: WHC/BCS Document Control Services, P.0. Box 1970, Mailstop H6-08, Richland WA 99352, Fhone (509) 372-2420; Fax (509) 376-4989.
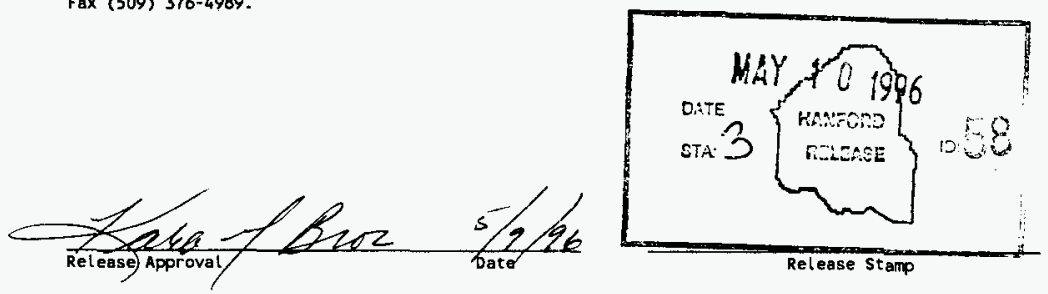

Approved for Public Release 
RECORD OF REVISION

(1) Document-Number

WHC-SD-WM-TP-243

(2) Title

TANK 241-AX-104 TANK CHARACTERIZATION PLAN

CHANGE CONIROL RECORD

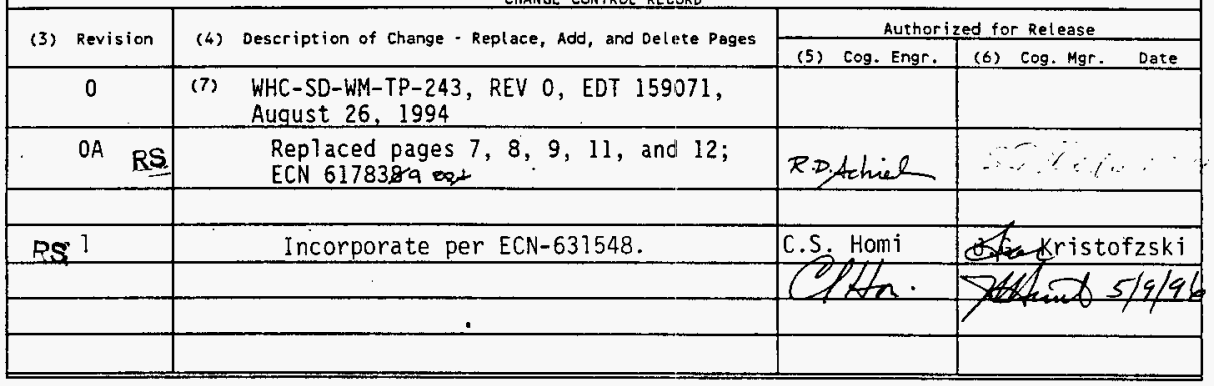


WHC-SD-WM-TP-243

Revision 1

UC-2070

\section{Tank 241-AX-104 Tank Characterization Plan}

C. J. Benar

Westinghouse Hanford Company

Date Published

May 1996

Prepared for the U.S. Department of Energy

Office of Environmental Restoration and

Waste Management

\section{We Westinghouse $\begin{aligned} & \text { P.o. Box } 990 \\ & \text { Hanford Company } \\ & \text { Richhna, Washington }\end{aligned}$}

Management and Operations Contractor for the

U.S. Department of Energy under Contract DE-AC06-87RL10930

Approved for Public Release 
WHC-SD-WM-TP-243, Rev. 1

TABLE OF CONTENTS

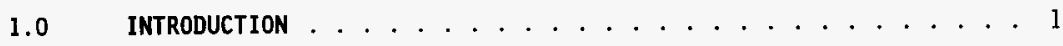

2.0 PROGRAM ELEMENTS REQUIRING INFORMATION FOR TANK 241-AX-104 . . . 1

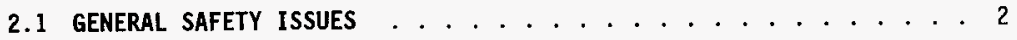

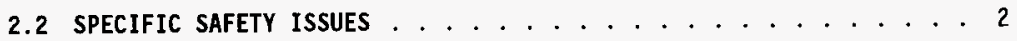

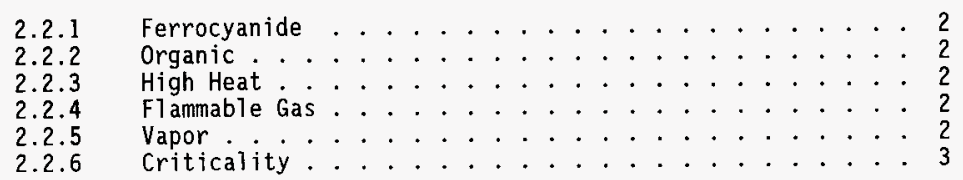

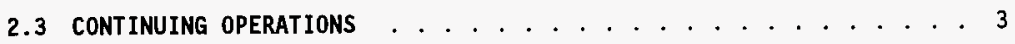

2.3.1 Compatibility/Stabilization ............ 3

2.3.2 Evaporator .................. 3

2.4 DOUBLE-SHELL TANK haSTE ANALYSIS PLAN ......... 3

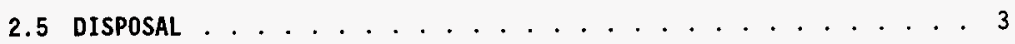

2.5.1 Retrieval ............... 3

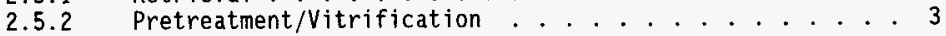

2.6 HISTORICAL MODEL EVALUATION . . . . . . . . . . . 3

3.0 HOW INFORMATION WILL BE OBTAINED ............. 4

4.0 PRIORITY OF INFORMATION REQUIREMENTS ............. 4

5.0 WHEN INFORMATION WILL BE AVAILABLE ........... 4

6.0 REFERENCES ................... 5

\section{LIST OF TABLES}

4-1 Integrated DQO Requirements and Priorities ......... 4 
WHC-SD-WM-TP-243, Rev. 1

\subsection{INTRODUCTION}

This Tank Characterization Plan (TCP) identifies the information needed to address relevant issues concerning short-term and long-term safe storage and long-term management of single shell tank 241-AX-104 (AX-104). It should be understood that the various needs and issues surrounding tank $A X-104$ are evolving as new information about the tank is uncovered. As a result of this progression, this TCP addresses only the issues that, to this date, have been identified. It is expected that deviations from this plan may occur as additional issues or needs arise which impact the management of tank AX-104. As necessary, this TCP will be revised to reflect those changes or deviations. This plan reflects the best information available as of May 1996.

Tank AX-104 was constructed in 1964 and entered into service in 1965. From third quarter of 1965 to fourth quarter of 1972 AX-104 received Plutonium Uranium Extraction (PUREX) waste. From the first quarter of 1973 to the second quarter of 1976, the tank contained PUREX sludge supernatant. Water was added in the second quarter of 1974. The tank contained evaporator feed from the third quarter of 1976 through the first quarter of 1978. Cesium feed was sluiced in the third quarter of 1976. The tank was sluiced for strontium and cesium recovery during the third quarter of 1977. In 1977 the tank was declared an assumed leaker with an approximate 8,000-gal leak volume. The leak was attributed to a vapor line and vessel vent header. A level adjustment was made during May 1978 and the tank was primary stabilized in September 1978. Tank AX104 is categorized as an assumed leaker and its waste is classified as noncomplexed (Brevick et a7. 1995).

This tank currently contains waste with a total waste volume of $27 \mathrm{~kL}$ (7 $\mathrm{kgal})$, which is equivalent to $6 \mathrm{~cm}(2 \mathrm{in})$ as measured from the baseline of the tank (Hanton 1996).

This tank is not on any Watch List.

Near-term sampling and analysis activities are focused on either verifying or changing the Watch List tank status, and identifying any new safety issues. Should any safety issues be identified, additional analysis will occur consistent with the identified issue.

In addition to the resolution of the safety issues, it is intended that all tank waste will be subject to pretreatment and retrieval to prepare for final storage or disposal. Presently, these long-range plans have yet to be fully identified and are, therefore, not included in this document.

\subsection{PROGRAM ELEMENTS REQUIRING INFORMATION FOR TANK 241-AX-104}

This section identifies the various program elements, and identifies which of these programs require characterization data from tank AX-104. 
WHC-SD-WM-TP-243, Rev. 1

\subsection{GENERAL SAFETY ISSUES}

The Tank Safety Screening Data Quality Objective (Dukelow et al. 1995) describes the sampling and analytical requirements that are used to screen waste tanks for unidentified safety issues. Analytical requirements for the safety screening of a tank are energetics, total alpha activity, moisture content, density, and flammable gas concentration.

\subsection{SPECIFIC SAFETY ISSUES}

\subsubsection{Ferrocyanide}

This tank is not on the Ferrocyanide Watch List; therefore, no information needs are currently identified for this program element.

\subsubsection{Organic}

This tank is not on the Organic Watch List; therefore, no information needs are currently identified for this program element.

\subsubsection{High Heat}

This tank is not on the High Heat Watch List; therefore, no information needs are currently identified for this program element.

\subsubsection{Flammable Gas}

This tank is not on the $\mathrm{Flammable} \mathrm{Gas} \mathrm{Watch} \mathrm{List;} \mathrm{therefore,} \mathrm{no} \mathrm{information}$ needs are currently identified for this program element.

\subsubsection{Vapor}

All 177 underground tanks must be vapor-sampled for organic solvent screening as per Recommendation 93-5 Implementation Plan (DOE-RL 1996). Some tanks may require additional vapor sampling due to other program needs. These tanks may be classified into four categories: (1) those tanks which are to be rotary mode core sampled (as a consequence of the rotary sampling system exhauster permit requirements); (2) tanks on the Organic or Ferrocyanide Watch Lists; (3) tanks in C farm; and (4) tank 241-BX-104, due to vapor exposure. Information needs must satisfy Data Quality Objectives for Tank Hazardous Vapor Safety Screening (0sborne and Buckley 1995), and for rotary mode only, Rotary Core Vapor Sampling Data Quality Objective (Price 1994), and Data Quality Objective for Regulatory Requirements for Hazardous and Radioactive Air Emissions Sampling and Analysis (Mulkey and Markillie 1995) as amended by Status of the Current Understanding of the Toxic Air Pollutants (TAPS) and Hanford Tank Farm Vapor Space Characterization; Recommended Path Forward and Justification for Cont inued RMCS Exhauster Operations (Laws 1996). 


\subsubsection{Criticality}

No information separate from that for the general safety issue of tank AX-104 are currently identified for this program element. However, if the general safety screening of tank AX-104 identifies a potential criticality concern, analyses for fissile materials and neutron sorbers and poisons will be performed as identified in the safety screening data quality objective (DQO).

\subsection{CONTINUING OPERATIONS}

\subsubsection{Compatibility/Stabilization}

This section does not apply to tank AX-104.

\subsubsection{Evaporator}

This section does not apply to tank AX-104.

\subsection{DOUBLE-SHELL TANK WASTE ANALYSIS PLAN}

This section does not apply because tank AX-104 is a single-shell tank.

\subsection{DISPOSAL}

\subsubsection{Retrieval}

Current retrieval needs (Bloom and Nguyen 1995) do not call for test samples to be taken from tank $A X-104$.

\subsubsection{Pretreatment/Vitrification}

Tank AX-104 has not been identified as a bounding tank for pretreatment/ disposal process development strategy (Kupfer et a1. 1995). All tanks were prioritized using the pretreatment strategy in the Tank Waste Characterization Plan and Basis (Brown et al. 1995) document and a portion of archive sample material could be used for pretreatment testing if available. The strategy does not require any specific analyses to be done on the samples.

\subsection{HISTORICAL MODEL EVALUATION}

Bounding tanks and data requirements for historical model evaluations are found in Historical Model Evaluation Data Requirements (Simpson and McCain 1995). Tank $A X-104$ is not identified as a primary bounding tank for historical model evaluations. 
WHC-SD-WM-TP-243, Rev. 1

\subsection{HOW INFORMATION WILL BE OBTAINED}

The number of samples required to characterize a tank is a function of waste heterogeneity and the desired confidence to make a correct decision. directed by the safety screening $D Q 0$, if iradequate information exists to determine an appropriate number of samples, two vertical profiles will be obtained. These vertical profiles may be obtained using core, auger (for shallow tanks), or grab samples. If analysis of these profiles reveals that additional profiles are necessary to meet clata needs, more sample profiles wi1l be requested.

\subsection{PRIORITY OF INFORMATION REQUIREMENTS}

Auger sampling was performed in February 1995 in accordance with Babad and Redus, (1995). Another auger sampling event is scheduled for January 1997 and a vapor sampling event for June 1997 (Stanton 1996). Refer to Table 4-1 for the current $\mathrm{DQO}$ requirements and planned sampling and analytical requirements.

Table 4-1: Integrated DQO Requirements and Priorities

\begin{tabular}{|l|l|l|l||}
\hline $\begin{array}{l}\text { Sampling } \\
\text { Event }\end{array}$ & \multicolumn{1}{|c||}{ Appl icable Issues } & Sampling Requirements & Analytical Requirements \\
\hline $\begin{array}{l}\text { Vapor } \\
\text { Sampling }\end{array}$ & $\begin{array}{l}\text {-Organic Solvent Layer } \\
\text { 93-5 Vapor Issue } \\
\text {-Hazardous Vapor DQO }\end{array}$ & $\begin{array}{l}\text { Steel canisters, } \\
\text { Triple Sorbent Traps, } \\
\text { Sorbent Trap Systems }\end{array}$ & $\begin{array}{l}\text { Flammable Gas } \\
\text { Organic Vapors } \\
\text { Permanent Gases }\end{array}$ \\
\hline $\begin{array}{l}\text { Auger } \\
\text { Sampling }\end{array}$ & -Safety Screening DQO & $\begin{array}{l}\text { 1 auger sample each } \\
\text { from 2 risers. } \\
\text { Combustible gas } \\
\text { measurement }\end{array}$ & $\begin{array}{l}\text { Flammability, Energetics, } \\
\text { Moisture, Total alpha } \\
\text { activity, Density }\end{array}$ \\
\hline
\end{tabular}

* Consult each applicable DQ0 in force at the time for sampling and analytical requirements.

\subsection{WHEN INFORMATION WILL BE AVAILABLE}

According to Stanton (1996) data are expected to be available from the January 1997 auger sampling event for tank AX-104 in May 1997. The vapor data are expected in August 1997. These times may be altered if the sampling schedule changes. 
WHC-SD-WM-TP-243, Rev. 1

\subsection{REFERENCES}

Babad, H. and K. Redus, 1994, Tank Safety Screening Data Quality Objective, WHC-SD-WM-SP-004, Rev. O, Westinghouse Hanford Company, Richland, Washington.

B1oom, G. R. and Q. H. Nguyen, 1995, Characterization Data Needs for Development, Design and Operation of Retrieval Equipment Developed Through the Data Quality Objective Process, WHC-SD-WM-DQ0-008, Rev. 0, Westinghouse Hanford Company, Richland, Washington.

Brevick, C. H., L. A. Gaddis, and W. W. Pickett, 1995, Historical Tank Content Estimate for the Northeast Quadrant of the Hanford 200 East Areas, WHC-SD-WM-ER-349, Rev. OA, ICF Kaiser Hanford Company, Richland, Washington.

Brown, T. M., S. J. Eberlein, and T. J. Kunthara, 1995, Tank Waste Characterization Basis, WHC-SD-WM-TA-164, Rev. 1, Westinghouse Hanford Company, Richland, Washington.

DOE-RL, 1996, Recommendation 93-5 Implementation P7an, D0E/RL-94-0001, Rev. 1, U.S. Department of Energy, Richland, Washington.

Dukelow, G. T., J. W. Hunt, H. Babad, and J. E. Meacham, 1995, Tank Safety Screening Data Quality Objective, WHC-SD-WM-SP-004, Rev. 2, Westinghouse Hanford Company, Richland, Washington.

Hanlon, B.M., 1996, Waste Tank Summary for Month Ending January 31, 1996, WHC-EP-0182-94, Westinghouse Hanford Company, Richland, Washington.

Kupfer, M. J., W. W. Schultz, and J. T. Slankas, 1995, Strategy for Sampling Hanford Site Tank Wastes for Development of Disposal Technology, WHC-SD-WM-TA-154, Rev. 1, Westinghouse Hanford Company, Richland, Washington.

Laws, G. L., 1996, Status of the Current Understanding of the Toxic Air Pollutants (TAPS) and Hanford Tank Farm Vapor Space Characterization; Recommended Path Forward and Just ification for Cont inued RMCS Exhauster Operations, (telephone conference memorandum, 01830-96-022, to Distribution, March 8) Westinghouse Hanford Company, Richland, Washington.

Mulkey, C.H., and K. D. Markillie, 1995, Data Quality Objective for Regulatory Requirements for Hazardous and Radioactive Air Emissions Sampling and Analysis, WHC-SD-WM-DQO-021, Rev. 0, Westinghouse Hanford Company, Rich1 and, Washington.

Osborne, J. W., L. L. Buckley, 1995, Data Quality Objectives for Tank Hazardous Vapor Safety Screening, WHC-SD-WM-DQO-002, Rev. 2, Westinghouse Hanford Company, Richland, Washington. 


\section{WHC-SD-WM-TP-243, ReV. 1}

Price, D. N., 1994, Rotary Core Vapor Sampling Data Quality Objective, WHC-SD-WM-SP-003, Rev. 0, Westinghouse Hanford Company, Richland, Washington.

Simpson, B. C., and D. J. McCain, 1995, Historical Model Evaluation Data Requirements, WHC-SD-WM-DQO-018, Rev. CA, Westinghouse Hanford Company, Richl and, Washington.

Stanton, G. A., 1996, Baseline Sampling Schedule, Change 96-02, (internal memo 75610-96-06, to Distribution, April 17), Westinghouse Hanford Company, Richland, Washington. 


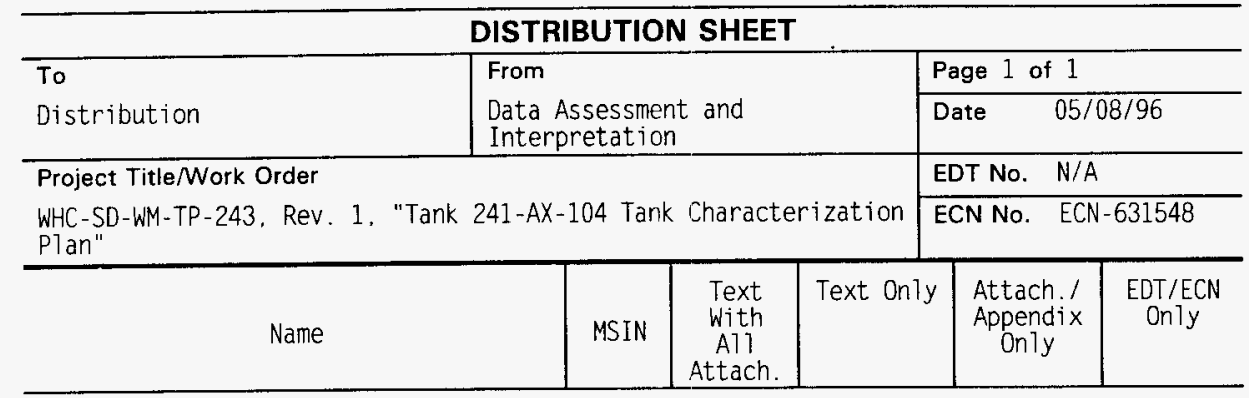

ONSITE

U. S. Department of Enerqy -

Richland Field office

W. Liou

N. W. Will is

Westinghouse Hanford Company

C. J. Benar

G. D. Forehand

C. S. Homi

Central Files

T.C.R.C.

$\begin{array}{ll}57-54 & x \\ \text { S7-54 } & x\end{array}$

R2-12

S7 -21

R2 -12

A3-88

R2-12 $x$
$x$

\section{OFFSITE}

U. S. Department of Energy - Headquarters

Office of Environmental Restoration and Waste Management EM-563

12800 Middlebrook Road

Germantown. MD 20874

J. A. Poppiti

$x$ 